\title{
The Design of Housing and Shelter Programs: The Social and Environmental Determinants of Inequalities
}

\author{
Shaaban Sheuya, Philippa Howden-Chapman, \\ and Sheela Patel
}

\begin{abstract}
Both developed and less developed countries are becoming increasingly urbanized. The earlier industrialized countries have developed more infrastructure to support the building of healthy housing, in neighborhoods that are strongly linked to municipal and global health initiatives, but to some degree housing and neighborhood issues vary only in degree between the developing and developed worlds. Overall, a billion people, a third of people living in urban areas, live in slums, where environmental determinants lead to disease. Although communicable diseases predominate in the developing world and have reemerged in the developed world, noncommunicable diseases are also growing disproportionately in the developing world. At a global level, the Millennium Development Goals explicitly focus on an integrated approach to slum upgrading. The per capita cost of slum upgrading is almost twice the cost of providing new affordable housing at the outset. It is argued that to improve health and well-being in the slums we need to have interventions that reduce urban poverty in the broadest sense and improve the deficiencies associated with slums. There is an urgent need to scale up the best-practice interventions. Examples are given of successful local community initiatives that have been set up under national strategies in Tanzania and by Indian women's collectives that are globally linked and have helped develop housing and sanitation improvements. The unit costs for such interventions are within the reach of all the key stakeholders. Global commitment is the only missing link.
\end{abstract}

KEYWORDS Housing programs, Urban areas, Slums

\section{INTRODUCTION}

Society has been completely urbanized. ${ }^{1}$

The world is increasingly becoming urban. By 2015, the target date for attaining the Millennium Development Goals (MDGs), it is estimated that more than half the world will live in urban areas, the majority in developing countries. By 2030 , it is predicted that two-thirds of people will be living in cities. ${ }^{2}$

\footnotetext{
Sheuya is with the University College of Lands and Architectural Studies (UCLAS), Dar es Salaam, Tanzania; Howden-Chapman is with the He Kainga Oranga/Housing and Health Research Program, Department of Public Health, University of Otago, Wellington, New Zealand; Patel is with the SPARC and Slum Dwellers International, P.O. Box 9389, Mumbai, 400026, India, http://www.sdinet.org/ index.html.

Correspondence: Shaaban Sheuya, University College of Lands and Architectural Studies (UCLAS), Dar es Salaam, Tanzania. (E-mail: sheuya@yahoo.com)
} 
Urbanization is not a new phenomenon, in the "developed" world it started more than 200 years ago. The industrial revolution led to high population growth and hastened migration from rural to urban areas. Whereas industrialization was accompanied by rapid economic growth, it also led to a rapid growth of inequality and degraded environmental conditions. Relatively strong governments, prodded by reform movements, meant institutions were eventually developed that were largely able to meet the urban needs of adequate shelter, clean water, and sanitation. ${ }^{3}$ Many actors, such as social reformers, town planners, engineers, architects, builders, the construction industry, property developers, and mortgage institutions, helped ensure the standards of private dwellings, neighborhoods, and municipalities. $^{4}$

Rapid urbanization in developing countries started much later and followed a different pattern. Although, these "new urban settings" followed the same sequence of rapid population increases, dramatic rural-urban migration rates and major environmental impacts, this was often accompanied by low or medium economic growth rates. ${ }^{5}$ The authorities responsible for managing the urban areas are often ill-equipped to meet the housing needs of the population influx. As a result, the majority of people live in slums*, where individual households build their houses incrementally by using their own savings. ${ }^{6,7}$

\section{SHELTER, HOUSING, INCOME, AND NEIGHBOURHOOD}

Adequate shelter has been defined as: "more than a roof over one's head, it means adequate privacy, adequate space, physical accessibility, adequate security of tenure, structural stability and durability, adequate lighting, heating and ventilation, adequate basic infrastructure such as water, sanitation, and waste management facilities, suitable environmental quality and health factors and adequate and accessible location with regard to work and basic facilities, all of which should be available at an affordable cost." ${ }^{\text {Th }}$ The absence of these housing necessities is seen as the defining characteristic of slums: lack of basic services; illegal or poor building structures; overcrowding and high density; inadequate access to sanitation and other infrastructure; inadequate access to safe water; hazardous locations; insecure tenure; and poverty leading to social exclusion. ${ }^{9}$

Housing includes the physical aspects of housing, such as the structural and design features (e.g., house type, space, warmth, and dryness), whereas the concept of home refers to the psychosocial dimension of housing and includes aspects of security, control, sense of attachment, permanence, and continuity. Neighborhood is the place where housing is located and which influences the provision of basic infrastructure and social services (schools, dispensaries, recreation). ${ }^{10}$

\footnotetext{
*Slum is a generic term used in the Knowledge Network on Urban Settings (KNUS) and is used here as a neutral term. Some activists and writers have concluded that slums can have negative connotations when inhabitants are referred to as slum-dwellers and prefer the term informal housing, to separate the people from their houses.

In 2000, one billion out of nearly three billion urban people were slum dwellers. Africa is leading with $61.3 \%$, followed by Asia (40.1\%) and Latin America and the Caribbean (32.3\%). Eastern European states have the least number of slum dwellers (6.6\%) and Western European and other countries $(9.6 \%){ }^{6}$
} 
Adequate housing requires adequate income. Definitions of income poverty have been used indiscriminately in rural and urban areas across the world, ${ }^{11}$ but often fail to take into account the interconnected infrastructure costs of housing, transport, and access to necessities such as water. This has led UN Habitat to define poverty in terms of the absence of safe, secure, and healthy shelter with basic infrastructure such as piped water and adequate provision for sanitation, drainage, and the removal of household wastes. ${ }^{8}$

This largely environmental view of urban poverty has also been broadened to include social and economic factors such as: inadequate, unstable, or risky asset base; limited or no safety net; inadequate protection of poorer groups' rights through the operation of the law; and poorer groups' voicelessness and powerlessness within political systems and bureaucratic structures. ${ }^{12}$ Thus, a more comprehensive understanding of urban poverty is not limited to inadequacies in housing and income, but sees these as structural factors that inhibit the formation of social cohesion and social capital, which can generate the trust and goodwill necessary for collective action. ${ }^{13}$

\section{UNDERSTANDING THE CONTRIBUTION OF HOUSING AND NEIGHBORHOODS TO HEALTH}

Galea and colleagues developed a model that explores the different social, economic, and environmental factors that influence health, and highlight the appropriate agencies and housing and neighborhood interventions needed to improve health and well-being (see Figure 1). ${ }^{14}$ The determinants of health and well-being are grouped as urban living conditions, municipal level determinants, and major global and national trends. The model depicts the importance of good governance at the local level and also establishes the important linkages that exist between municipal governments and external forces such as globalization in influencing health and well-being.

Supporting the model, a number of reviews have documented the evidence of the linkages between housing and the social determinants of health. ${ }^{5,10,15,16}$ Whereas the common diseases are different in developed and developing countries, the underlying determinants are similar. Communicable diseases, which account for two-thirds of the deaths in Africa, account for less than $10 \%$ of deaths in Europe. ${ }^{17}$ However, recent studies suggest that developing countries with the highest levels of urbanization are experiencing a reversal of this pattern, and generally the transition is first noted in urban areas. ${ }^{18}$

Most communicable diseases are associated with the conditions that characterize slums, and indeed, substandard housing in developed countries. Environmental factors, including housing, are estimated to account for $25 \%$ of all preventable ill-health, with diarrheal diseases and acute respiratory infections leading the list. ${ }^{19}$

There is a strong causal relationship between ill health and exposure to chemical, physical, and biological agents. For example, the ingestion of particles of lead paint or absorption of lead from pipes can lead to irreversible damage to intellectual growth and increased behavior problems, ${ }^{20}$ and asbestos is carcinogenic, but discarded sheets are often used in constructing shanty towns. ${ }^{21}$

In developing regions of the world, the unvented burning of biomass for cooking and heating produces a toxic and deadly mixture of pollutants. It is 


\begin{tabular}{|c|c|c|}
\hline Urban living conditions & $\begin{array}{l}\text { Municipal } \\
\text { level } \\
\text { determinants }\end{array}$ & $\begin{array}{l}\text { Major global } \\
\text { and national } \\
\text { trends }\end{array}$ \\
\hline $\begin{array}{l}\text { Population: } \\
\text { Demographics, } \\
\text { social } \\
\text { economic } \\
\text { status, } \\
\text { ethnicity, } \\
\text { attitudes, } \\
\text { behaviors }\end{array}$ & $\begin{array}{l}\text { Government } \\
\text { policies and } \\
\text { practices at } \\
\text { all levels as } \\
\text { implemented } \\
\text { in cities }\end{array}$ & \\
\hline \begin{tabular}{|l}
\multicolumn{1}{c}{15} \\
Physical \\
environment: \\
Housing, \\
density, built \\
environment, \\
pollution
\end{tabular} & $\begin{array}{l}\quad \widetilde{1} \\
\text { Markets: } \\
\text { Food, } \\
\text { housing, } \\
\text { labor, other } \\
\text { goods }\end{array}$ & $\begin{array}{l}\text { Immigration, } \\
\text { Sub } \\
\text { urbanization, } \\
\text { changes in } \\
\text { role of } \\
\text { government, } \\
\text { globalization }\end{array}$ \\
\hline $\begin{array}{l}\text { Social } \\
\text { environment: } \\
\text { Social } \\
\text { networks, } \\
\text { social support, } \\
\text { social capital }\end{array}$ & $\begin{array}{l}\text { Civil society: } \\
\text { Community } \\
\text { organizations, } \\
\text { Community } \\
\text { capacity, social } \\
\text { movements }\end{array}$ & \\
\hline
\end{tabular}

FIGURE 1. Determinants of health according to Galea et al. Source: Galea et al., ${ }^{14}$ with modifications.

estimated that more than two million people, mainly women and children, die each year because of this. ${ }^{22}$ However, household heating and cooling is also a problem in more developed countries as some poor households in temperate countries use minimal heating and cooling. ${ }^{23,24}$ As oil and other energy prices rise, this is likely to be an increasing problem.

The use of unvented fuels for cooking and heating can also cause high relative humidities leading to dampness-ideal habitats for viruses, ${ }^{25}$ house dust mites, 
cockroaches, and mold, all of which cause major respiratory problems. ${ }^{22,26-28}$ Dampness and mold are also often by-products of poor construction or deferred maintenance in older buildings because of housing costs. ${ }^{29}$

Environmental tobacco smoke from indoor cigarette smoking is another combustion product, which causes respiratory problems, lung cancer in adults, low birth weight, asthma, bronchitis, pneumonia, and ear infections in children. ${ }^{30}$ Poorly constructed or maintained houses and neighborhoods ${ }^{31}$ create injury hazards ${ }^{32}$ and breeding grounds for mice and rats, flies, and cockroaches. ${ }^{33}$ Unsafe water and poor sanitation are linked with diarrheal diseases and food insecurity and malnutrition with parasitic infections. ${ }^{5}$

Whereas traditional indigenous housing of most countries has been reasonably well adapted to the local climate, several major factors have made some of these designs less adaptive, and some of the quality of housing has been lost with poor modern design or cheap building materials. Traditional housing is usually one or two-storey or stand-alone, but in modern cities, permanent housing (and office building) designs are more often three-dimensional (taller). Tall buildings can create shading/canyon effects and make ventilation trickier. Secondly, climate change is leading to more extreme weather events, such as more extremes of hot and cold, and risk of flooding affecting low-lying housing areas. ${ }^{34}$ The recent hurricane in New Orleans has demonstrated that not only are low-income housing areas more likely to be in more vulnerable low-lying areas, but also that in emergencies, civil defense efforts and subsequent reconstruction efforts do not favor the poor. ${ }^{35,36}$

A high number of deaths in Europe in 2003 and in some United States cities in recent years has been attributed to a lack of adequate ventilation of apartments and the lack of social support for the older people trapped in them. ${ }^{37}$ Low-income households often cannot afford air conditioning and it may be difficult to purchase fans during heat waves. Moreover, low-income areas are less likely to be in housing surrounded by trees or shrubs, which can provide a cooling effect and encourage recreation. $^{38}$

At a social level, tenure is strongly related to health; those who own their own homes and have security of tenure, are usually in better health. ${ }^{39}$ Household density and crowding, more common in rental properties, has been related to communicable diseases such as tuberculosis and meningococcal disease. ${ }^{40}$ Crowding and living in poorly maintained high-rise building has also been associated with mental health problems and fear of crime.

Whereas there is still a lack of housing and health research that specifically looks at current urbanization trends, ${ }^{41}$ there are many areas where precautionary action is justified. Urban form in developed countries is increasing being linked to the level of physical activity and hence to health. ${ }^{42}$ The amenities identified as being important for health are also important in developing countries. Measures of mixed land use, more residential density, and greater street connectivity (intersection density) have been positively related to higher levels of physical activity and lower levels of obesity. ${ }^{43}$ Access to parks and green spaces has also been shown to increase levels of exercise, ${ }^{38,44}$ particularly when people feel safe in their neighborhood, ${ }^{45}$ and provide cooling in heat waves. Physical symptoms of neighborhood decline such as rubbish, graffiti, and broken windows and social symptoms such as segregation, loitering, and increased crime, have an impact on health at a neighborhood level. ${ }^{46,47}$ Houses by roads are more vulnerable to pollution and noise exposure, which is damaging to occupants' health. ${ }^{48}$ 


\section{AN INTEGRATED APPROACH TO COMBATING POVERTY AND IMPROVING HOUSING}

The MDGs provide a unique global opportunity for an integrated approach to combating poverty and improving the health and well-being of all people who live in slums. Goal One aims to halve the proportion of people whose income is less than US \$1 a day, and who suffer from hunger by 2015. Goal Seven aims to halve the proportion of people who live without safe water and basic sanitation by 2015 , make significant improvements in the lives of 100 million slum dwellers by 2020 , and concurrently create permanent healthy affordable housing. ${ }^{7}$

We need to be proactive in terms of urban planning, otherwise we may end up just upgrading slums, an expensive and unsustainable response. Calculations of the costs needed to meet Goal Seven show that it takes only US \$25 per person per year over 15 years to provide new affordable housing, but US $\$ 42$ per person per year to upgrade slums. ${ }^{5}$ Thus, slum upgrading is not only at best, a short-term solution, it is also a more expensive one than providing affordable long-term housing at the outset.

The global mandate to lead others to reduce health inequalities lies with the World Health Organisation (WHO), and one of its key functions is to work with member states and other specialized agencies to "promote ... the improvement of nutrition, housing, sanitation, recreation, economic or working conditions and other aspects of environmental health (emphasis added). ${ }^{49}$ The WHO and the Commission on the Social Determinants of Health (CSDH) have been challenged to take the leading role in working out sustainable solutions. The questions are: How can this be achieved through the design of housing and shelter programs? What are the existing "best practice" interventions? How can they be scaled up?

\section{EXISTING BEST PRACTICES}

Interventions aimed at improving housing and neighborhoods have been carried out in different parts of the world with encouraging results. A quick glance at the interventions could lead to the conclusion that they focus on changing the physical environment. For us, changing the physical environment should go side-by-side with changing the social environment. For example, providing reliable public transport systems, which enable people to get safely to work, school, the market and visit friends and family, provides the physical infrastructure to support social networks and social capital.

A number of systematic reviews have looked at the health effects of housing improvements in developed countries, such as rehousing, refurbishment, and energy efficiency measures. ${ }^{50,51,52}$ Some studies have shown significant health gains after housing interventions, ${ }^{53}$ but well-funded British urban regeneration programs have shown little impact. ${ }^{54}$ However, structural improvements, which are often joint efforts between local and national governments and nongovernment organizations, social organizations such as neighborhood watch groups can help more vulnerable members of the community, such as elderly or disabled people, when there are extreme weather events.

UN Habitat has been extensively documenting best practices that effectively address the most critical problems in human settlement development, and interventions in the environment, housing, urban governance, and urban planning top the list. The interventions in the developing world address issues related to slum 
upgrading, promotion and capacity building of community-based organizations, adopting enabling building codes and planning standards, solid waste management, promotion of informal businesses, issuance of micro-finance, and integrating transport and land-use planning."

The WHO Kobe Centre (2005) has similarly identified five strategic interventions that can lead to the improvement of health and well-being of the people living in slums: slum upgrading, sustainable urban development, improving access to quality health care, targeted health care promotion, and integration of health, welfare, and education services. Clearly, changing the physical environment should address more than one aspect of the broad definition of poverty and needs creation of space for the participation and empowerment of individual households, community-based organizations, municipal and national governments. It must involve the creation of meaningful and collaborative partnerships among all these parties.

Experience gained from the developing world shows that successful interventions have to incorporate the social dimension. For example, the empowerment of slum dwellers must support their associations, even their formation if necessary, and upskill them to increase their influence and control within bureaucratic structures and political systems. ${ }^{55}$ Scaling up the success stories gained from these "best practice" interventions holds hope for the future.

\section{CASE STUDIES}

In this paper we briefly highlight two best-practice interventions from developing countries: Community Development Committees (CDCs) operating within the Cities Without Slums initiative in Arusha City in Tanzania and the global initiatives of the Shack Dwellers International.

The Tanzanian Government has a progressive housing policy. The policy states that slum upgrading shall be done "by their inhabitants through CBOs and NGOs with the government playing a facilitating role."56 Based on the policy and the National Strategy for Growth and Reduction of Poverty, the Arusha City Council worked with pilot CDCs from two wards. The CDCs were empowered to become the de facto basic units for the formulation and implementation of the upgrading proposals. They also elected members to represent them in a restructured city council.

The CDCs identified environmental issues that they could solve themselves, e.g., plot subdivision and solid waste management and those which needed technical and financial assistance from the city council, such as construction of major roads. The per capita cost for slum upgrading was roughly US $\$ 32$, a figure that compares favorably with the costs estimated by the MDGs. Donors are being sought to facilitate this process in the remaining 15 wards of Arusha City.

Our second case study addresses the problems of the rural landless poor, who move to urban areas and are, by and large, totally excluded from the large social movements of urban workers and are not recognized as city residents, contributing to the city and seeking equity in the form of basic amenities and services. The Shack Dwellers International undertakes an organizational aggregation process, which it

\footnotetext{
*( http://bestpractises.org/bpbriefs/analysis.html)
} 
terms the "federation model," to build up strategic and practical skills of these people for advocacy and creating credit at micro levels. Successful local solutions through this global network created a communication channel that enhances the opportunities for advocacy. For example, in Mumbai, India a network of community leaders from informal settlements and women's collectives addressed the problem of dangerous roofing materials such as discarded asbestos sheets, by searching out an innovative, affordable, flexible construction roofing tile called Laadi, which is made of sandstone and cement and can be prefabricated for collective constructions. Following this experience, collectives of pavement dwellers in the Philippines and Kenya sought dialogue with local and national governments to map out communities vulnerable to flooding and to seek policies from the governments that are community-managed and community-driven.

\section{CONCLUSIONS}

The world has become increasingly urbanized and improving houses and neighborhoods for those who live in poor-quality houses and neighborhoods is an urgent community and policy problem. Some of the causal links between housing and health are clear and there are similarities in kind, if not degree, between areas of low-income housing in the industrialized world and slums in the developing world.

We have argued that whereas the responsibility to improve health rests on each one of us-individual slum dwellers, civil associations, NGOs, municipal and national governments, the private sector, and the international community, not all have equal power or leverage. To improve health and well-being in the slums in the developing countries, we need to have interventions that target: (1) reducing urban poverty, which is defined in a broad and more comprehensive sense than the conventional income poverty, and (2) improving the deficiencies associated with the operational definition of slums.

Best-practice interventions have the potential for upscaling sustainable solutions and there is an urgent need to replicate them. Examples have been given of successful local community initiatives that have been set up under national strategies in Tanzania and by Indian women's collectives that are globally linked and have helped develop housing improvements. The per capita costs for such interventions are within the reach of all the key stakeholders. The message here is clear: meaningful and collaborative approaches among the individuals, municipal and national governments, and the international community are a prerequisite for attaining health and well-being. Global commitment is the only missing link.

\section{ACKNOWLEDGEMENTS}

The authors would like to thank Professors Tord Kjellstrom and Ralph Chapman for their comments and PLHC would like to acknowledge funding from the Health Research Council of New Zealand.

\section{REFERENCES}

1. Lefebvre H. The Urban Revolution. Minneapolis: University of Minnesota Press; 2003.

2. UN Habitat. Cities in a Globalizing World. London and Sterling: Earthscan; 2001.

3. Troesken W. Water, Race and Disease. Pittsburgh: MIT Press; 2004. 
4. Bourdieu P. Social Structure of the Economy. Cambridge: Polity Press; 2005.

5. WHO. A Billion Voices: Listening and Responding to the Health Needs of Slum Dwellers and Informal Settlers in the New Settings. WHO Kobe Center: Kobe; 2005.

6. Sheuya S. Housing Transformations and Urban Livelihoods in Informal Settlements, in SPRING Research Series No. 45. Dortmund; 2004.

7. UN Habitat. Financing Urban Shelter. London and Sterling: Earthscan; 2005.

8. UN Habitat. An Urbanizing World. Oxford: Oxford University Press; 1996.

9. UN Habitat. The Challenge of Slums. London and Sterling: Earthscan; 2003.

10. Canadian Institute for Health Information, Housing and Population Health. The State of Current Research and Knowledge. Ottawa: CIHI; 2004.

11. Chambers R. Poverty and livelihoods: whose reality counts? Environ Urban. 1995;7:173204.

12. Satterthwaite D. The under-estimation of urban poverty in low and middle-income nations. IIED; 2004.

13. Carpiano RM. Toward a neighbourhood resource-based theory of social capital for health: can Bourdieu and sociology help? Soc Sci Med. 2006;62:165-175.

14. Galea S, Freudenberg N, Vlahov D. Cities and population health. Soc Sci Med. 2005;60:1017-1033.

15. Krieger J, Higgins D. Housing and health: time again for public health action. Am J Public Health. 2002;92(5):758-768.

16. Howden-Chapman P. Housing standards: a glossary of housing and health. J Epidemiol Community Health. 2004;58:162-168.

17. Ratzan SC, Filerman GL, LeSar JW. Attaining global health: challenges and opportunities. Popul Bull. 2000;55(1).

18. Harpham T, Molyneux C. Urban health in developing countries: a review. Prog Dev Stud. 2001;1(2):113-137.

19. WHO. The World Health Report 1998: Life in the Twenty-first Century: a Vision for All. Geneva: WHO; 1998.

20. Jacobs DE. Housing and health: challenges and opportunities. In: Proceedings of the Second WHO International Housing and Health Symposium. Vilnius, Lithuania: WHO Europe; 2004.

21. U.S. Environmental Protection Agency Office of Research and Development. Airborne Asbestos Health Assessment Update, In: EPA-600-8-84-003F. 1986.

22. Sundell J. On the history of indoor air quality and health. Indoor Air. 2004;14:51-58.

23. Boardman B. Fuel Poverty: from Cold Homes to Affordable Warmth. London: Belhaven Press; 1991.

24. Healy JD. Housing, Fuel Poverty and Health: A pan-European Analysis. Aldershot: Ashgate; 2004.

25. Hersoug L-G. Viruses as the causative agent related to 'dampness' and the missing link between allergen exposure and onset of allergic disease. Indoor Air. 2005;15:363366.

26. Bornehag C-G, et al. NORDDAMP: Dampness in building and health. Indoor Air. 2001;11:72-86.

27. Platt SD, et al. Damp housing, mould growth, and symptomatic health state. $\mathrm{Br}$ Med J. 1989;298:1673-1678.

28. Hyndman SJ. Housing dampness and health amongst British Bengalis in East London. Soc Sci Med. 1990;30:131-141.

29. Howden-Chapman P, et al. Risk factors for mould. Indoor Air. 2005;15:469-476.

30. Thomson G, Wilson N, Howden-Chapman P. Population-level policy options for increasing the prevalence of smoke-free homes. J Epidemiol Community Health. 2006;60:298-304.

31. The Eurowinter Group. Cold exposure and winter mortality form ischaemic heart disease, cerebrovascular disease, respiratory disease, and all causes in warm and cold regions of Europe. Lancet. 1997;349:1341-1346. 
32. Ormandy D. Safe as houses? A Review of the Causes of Home Accidents. In: Second WHO International Housing and Health Symposium. Vilnius, Lithuania: WHO Europe; 2004.

33. Howard M. The Effects on Human Health of Pest Infestation. In: Burridge R, Ormandy D, eds. Houses in Unhealthy Housing: Research, Remedies and Reform. London: E \& FN Spon; 1993:256-282.

34. Wildner M, et al., eds. Extreme Weather Events and Public Health Responses. Heidelberg: Springer-Verlag; 2005.

35. Strom S. From foreign experts who helped, poor marks for Red Cross's hurricane efforts, in New York Times. April 5 2006, p. 16.

36. Dewan S, et al. Evacuees' Lives Still Upended Seven Months After Hurricane, in New York Times. March 22 2006,. p. 1.

37. Hales S, Woodward A. Potential Health Impacts and Policy Responses. In: Chapman R, Boston J, Schwass M, eds. Confronting Climate Change: Critical Issues for New Zealand. Wellington: Victoria University Press; 2006:117-123.

38. Ellaway A, Macintyre S, Bonnefoy X. Grafitti, greenery and obesity in adults: secondary analysis of European cross-sectional study. Br J Med. 2005;331:611-612.

39. Macintyre S, et al. Housing Tenure and Health Inequalities: A Three-Dimensional Perspective on People, Homes and Neighbourhoods. In: Graham H, ed. Understanding Health Inequalities. Buckingham: Open University Press; 2001.

40. Baker M, et al. Household crowding a major risk factor for meningococcal disease in Auckland children. Pediatr Infect Dis J. 2000;19:983-990.

41. Bonnefoy X. The Policy Relevance of Housing and Health - an International Perspective. In: Proceedings of the Second International Housing and Health Symposium. Vilnius: Lithuania; 2004.

42. McIndoe G, et al. The Value of Urban Design: The Economic, Environmental and Social Benefits of Urban Design. Wellington: Ministry for the Environment, Wellington City Council, Auckland Regional Council; 2005.

43. Frank LD, et al. Linking objectively measured physical activity with objectively measured urban form findings from SMARTRAQ. Am J Prev Med. 2005;28(2S2): $117-125$.

44. WHO Regional Office for Europe, LARES: Large Analysis and Review of European housing and health Status. 2006, European Centre for Environment and Health, WHO Regional Office for Europe: Bonn.

45. Shenessa ED, Liebhaber A, Ezeamama A. Perceived safety of area of residence and exercise: a pan-European study. Am J Epidemiol. 2006;163(11):1012-1017.

46. Macintyre S, Ellaway A. Ecological approaches: Rediscovering the Role of the Physical and Social Environment. In: Berkman LF, Kawachi I, eds. Social Epidemiology. Oxford: Oxford University Press; 2002.

47. Latkin CA, Curry AD. Stressful neighbourhoods and depression: a prospective study of neighbourhood disorder. J Health Soc Behav. 2003;44:34-44.

48. Ellaway A, et al. Perceptions of place and health in socially contrasting neighbourhoods. Urban Stud. 2001;38(12):2299-2316.

49. WHO. Action on the Social Determinants of Health: Learning from Previous Experiences. Kobe: WHO Kobe Center; 2005b.

50. Thomson H, Petticrew M, Morrison D. Health effects of housing improvement: systematic review of intervention studies. Br Med J. 2001;323:187-190.

51. Thomson H, Petticrew M, Douglas M. Health impact assessment of housing improvements: incorporating research evidence. J Epidemiol Community Health. 2003;57:11-16.

52. Richardson G, et al. The Watcombe housing study: the short-term effect of improving housing conditions on the indoor environment. Sci Total Environ. 2006;361:73-80.

53. Howden-Chapman P, et al. Retrofitting houses with insulation to reduce health inequalities: results of a clustered, randomised trial in a community setting. $\mathrm{Br} \mathrm{Med}$., in press. 
54. Thomson H, et al. Do urban regeneration programmes improve public health and reduce health inequalities? A synthesis of the evidence from UK policy and practice (19802004). J Epidemiol Community Health. 2006;60:108-115.

55. Lyons M, Smuts C, Stephens A. Participation, empowerment and sustainability: (how) do the links work? Urban Stud. 2001;38(8):1233-1251.

56. United Republic of Tanzania. National Human Settlements Development Policy. 2000. 